\title{
A screening assay for thyroid hormone signaling disruption based on thyroid hormone-response gene expression analysis in the frog Pelophylax nigromaculatus
}

\author{
Yinfeng Zhang ${ }^{1,2}$, Yuanyuan $\mathrm{Li}^{1}$, Zhanfen Qin ${ }^{1, *}$, Huili Wang ${ }^{2, *}$, Jianzhong $\mathrm{Li}^{2}$ \\ 1. State Key Laboratory of Environmental Chemistry and Ecotoxicology, Research Center for Eco-environmental Sciences, Chinese Academy of \\ Sciences, Beijing 100085, China. E-mail: lingboxian.yin@163.com \\ 2. Department of Environmental Bio-Technology, Research Center for Eco-environmental Sciences, Chinese Academy of Sciences, Beijing \\ 100085, China
}

\section{A R T I C L E I N F O}

Article history:

Received 4 October 2014

Revised 30 December 2014

Accepted 16 January 2015

Available online 3 June 2015

Keywords:

Thyroid hormone signaling disruptor

Pelophylax nigromaculatus

TH-response gene expression

Screening assay

Tetrabromobisphenol A

\begin{abstract}
A B S T R A C T
Amphibian metamorphosis provides a wonderful model to study the thyroid hormone (TH) signaling disrupting activity of environmental chemicals, with Xenopus laevis as the most commonly used species. This study aimed to establish a rapid and sensitive screening assay based on TH-response gene expression analysis using Pelophylax nigromaculatus, a native frog species distributed widely in East Asia, especially in China. To achieve this, five candidate TH-response genes that were sensitive to T3 induction were chosen as molecular markers, and T3 induction was determined as $0.2 \mathrm{nmol} / \mathrm{L}$ T3 exposure for $48 \mathrm{hr}$. The developed assay can detect the agonistic activity of T3 with a lowest observed effective concentration of $0.001 \mathrm{nmol} / \mathrm{L}$ and EC50 at around $0.118-1.229 \mathrm{nmol} / \mathrm{L}$, exhibiting comparable or higher sensitivity than previously reported assays. We further validated the efficiency of the developed assay by detecting the TH signaling disrupting activity of tetrabromobisphenol A (TBBPA), a known TH signaling disruptor. In accordance with previous reports, we found a weak TH agonistic activity for TBBPA in the absence of T3, whereas a TH antagonistic activity was found for TBBPA at higher concentrations in the presence of $\mathrm{T} 3$, showing that the $\mathrm{P}$. nigromaculatus assay is effective for detecting $\mathrm{TH}$ signaling disrupting activity. Importantly, we observed non-monotonic dose-dependent disrupting activity of TBBPA in the presence of T3, which is difficult to detect with in vitro reporter gene assays. Overall, the developed P. nigromaculatus assay can be used to screen TH signaling disrupting activity of environmental chemicals with high sensitivity. (c) 2015 The Research Center for Eco-Environmental Sciences, Chinese Academy of Sciences.
\end{abstract}

Published by Elsevier B.V.

\section{Introduction}

Thyroid hormones (THs) are critical for vertebrate growth, development, metabolic balance, and particularly brain organization and functions throughout life (Mullur et al., 2014; Remaud et al., 2014; Yen, 2001). TH (notably T3) actions are predominantly mediated by TH signaling, which involves TH-response gene transcriptional regulation by $\mathrm{TH}$ receptors (TRs, TR $\alpha$ and TR $\beta$ ) (Zhang and Lazar, 2000). Additionally, the

\footnotetext{
* Corresponding authors. E-mail: qinzhanfen@rcees.ac.cn (Zhanfen Qin), huiliwang@rcees.ac.cn (Huili Wang).
} 
transcriptional activation requires the release of corepressors and recruitment of coactivators to the complex of TR associating with retinoid $\mathrm{X}$ receptor (RXR) (Astapova and Hollenberg, 2013).

With similar chemical structures to THs, some environmental chemicals, such as hydroxyl polychlorinated biphenyls (OH-PCBs), hydroxyl polybrominated diphenylethers (OH-PBDEs), bisphenol A and its derivatives, and perfluorinated chemicals, have been shown to disrupt TH signaling by binding to TR (Boas et al., 2012; Ren et al., 2013, 2015). To detect the TH signaling disrupting activity of chemicals, several research groups developed in vitro bioassays, which were based on transcription analysis of reporter enzymes as a consequence of TR activation in mammalian cells or yeasts (Freitas et al., 2011; Zoeller et al., 2007). For example, Matsubara et al. (2012) developed a reporter gene assay using a pituitary cell line to detect the TH-signaling disruption activities of environmental chemicals (Matsubara et al., 2012), whereas Shiizaki et al. (2010) established a reporter yeast for screening $\mathrm{TR} \alpha$ and $\mathrm{TR} \beta$ ligands to examine their response to endogenous THs and chemicals. Due to the lack of complex interaction of cofactors with TRs, however, these in vitro bioassays are not potent enough to detect the $\mathrm{TH}$ signaling disrupting effects of chemicals in vivo (Zoeller et al., 2007). For example, Ishihara et al. (2011) reported that 5$500 \mathrm{nmol} / \mathrm{L} \mathrm{OH}-\mathrm{PCBs}$ caused an alteration of TH-response gene expression as well as a delay of T3-induced vertebrate development, demonstrating TH signaling disrupting activity, but no $\mathrm{TH}$ signaling disrupting activity was observed in a T3-dependent reporter gene assay in vitro. Therefore, it is necessary to develop simple and rapid in vivo screening methods that can sufficiently detect $\mathrm{TH}$ signaling disrupting activity (Coady et al., 2010; Shi, 2009).

Given that amphibian metamorphosis serves as an ideal model for studying TH actions (Laudet, 2011; Opitz et al., 2005; Tata, 1993), this model has begun to be used to investigate the TH signaling disruption of chemicals (Veldhoen et al., 2006, 2014b; Zhang et al., 2014). In this model, pre-metamorphic tadpoles, which can be induced by $\mathrm{TH}$ to metamorphose precociously, are treated with test chemicals in the presence or absence of TH for several days. At the end of treatment, if a chemical inhibits TH-induced metamorphosis at morphological and transcriptional levels, this chemical will be determined to be a TH signaling antagonist. In contrast, if a chemical promotes metamorphosis at morphological and transcriptional levels in the presence or absence of $\mathrm{TH}$, this chemical will be determined as TH signaling agonist (Heimeier et al., 2009; Zhang et al., 2014). So far, the model organism Xenopus laevis is the most commonly used species to study TH signaling disruption (Crump et al., 2002; Fini et al., 2007; Searcy et al., 2012; Zhang et al., 2014). Also, certain native amphibian species are promising as test species for $\mathrm{TH}$ signaling disruption research (Hammond et al., 2013; Helbing et al., 2006; Veldhoen et al., 2014a). The black-spotted frog (Pelophylax nigromaculatus, formerly Rana nigromaculata) is a native frog species widespread in East Asia. This species has been used in toxicological studies as well as biological studies for decades (Freytag et al., 1953; Jia et al., 2014; Huang et al., 2014). Furthermore, our research group has recently presented the utilizability of $P$. nigromaculatus as a test species for assaying the TH signaling disrupting activity of chemicals (Ge et al., 2014; Lou et al., 2014a,b)

In this study, we aimed to develop a simple and rapid screening assay for $\mathrm{TH}$ signaling disruption based on the expression analysis of $\mathrm{TH}$-response genes in $\mathrm{P}$. nigromaculatus intestines, including the selection of $\mathrm{TH}$-response genes sensitive to $\mathrm{TH}$ induction as well as the selection of an appropriate time and concentration for $\mathrm{TH}$ induction. Furthermore, we applied this assay to detect the $\mathrm{TH}$ signaling disrupting action of the flame retardant tetrabromobisphenol A (TBBPA), a known TH signaling disruptor, to validate the screening assay established (Jagnytsch et al., 2006; Terasaki et al., 2011; Zhang et al., 2014).

\section{Materials and methods}

\subsection{Chemicals}

T3 (purchased from Geel Belgium, New Jersey, USA) was dissolved in ultrapure water with $\mathrm{NaOH}$ to prepare a stock solution (6.60 g/L). Dimethyl sulfoxide (DMSO) and 3aminobenzoic acid ethyl ester (MS-222) were from SigmaAldrich (St. Louis, MO, USA). A stock solution of TBBPA (54.4 g/L, obtained from Geel Belgium) was prepared in DMSO. Luteinizing hormone releasing hormone (LHRH) was from Ningbo Second Hormone factory (Zhejiang, China). Human chorionic gonadotropin (HCG) was purchased from Yantai north pharmaceutical Co. Ltd. (Shandong, China). TRIzol, Fast Quant RT Kit, Real Master Mix (SYBR Green) Kit, RNase-free water, and ethidium bromide (EB) were purchased from Tiangen (Beijing, China). PCR primers were synthesized by Sangon Biotech (Beijing, China).

\subsection{Animals}

P. nigromaculatus frogs (from our amphibian house) were maintained in glass tanks containing charcoal-filtered tap water and fed with Terzebrio molitor daily. Housing and breeding conditions were reported in our previous study (Lou et al., 2014a). The water quality was as follows: without chlorine, iodine concentration 2-4 $\mu \mathrm{g} / \mathrm{L}, \mathrm{pH}$ 6.5-7.0, dissolved oxygen concentration $>5 \mathrm{mg} / \mathrm{L}$, and water hardness $\left(\mathrm{CaCO}_{3}\right)$ approximately $150 \mathrm{mg} / \mathrm{L}$. Fluorescent lighting provided a photoperiod of $12 \mathrm{hr}$ light/12 hr dark. Water temperature was maintained at $24^{\circ} \mathrm{C} \pm 1^{\circ} \mathrm{C}$. Adult frogs were induced to breed by injecting $25 \mu \mathrm{g}$ LHRH and HCG (male $200 \mathrm{IU}$, female $300 \mathrm{IU})$ accompanied by simulating rainfall. Fertilized eggs were incubated in the dechlorinated tap water at $24^{\circ} \mathrm{C} \pm 1^{\circ} \mathrm{C}$. On the fifth day post-fertilization, the tadpoles were fed with commercial diets (Totoro Supplies, Hong Kong, China) twice daily. The tadpoles were staged according to the Gosner system (1960).

\subsection{Expression analysis for candidate TH-response genes in the intestine during metamorphosis}

$\mathrm{TR} \alpha$, TR $\beta$, basic transcription element binding protein (BTEB), TH-responsive basic leucine zipper transcription factor (TH/ bZIP), matrix metalloproteinase 2 (MMP2), and sonic hedgehog 
(SHH) have been demonstrated to be TH-response genes in $\mathrm{X}$. laevis (Fini et al., 2012a; Hasebe et al., 2011; Heimeier et al., 2009). Their expression levels in the intestine parallel endogenous $\mathrm{TH}$ levels (Heimeier et al., 2010; Hoopfer et al., 2002; Wang et al., 2008). Changes in TH-response gene expression levels during metamorphosis can reflect to some degree the responsiveness of TH-response genes to TH. Here, we chose these genes as candidate TH-response genes in P. nigromaculatus intestines, and investigated the developmental expression profiles during metamorphosis, in order to understand the relationship between their expression and endogenous TH levels. Four genes (TH/bZIP, MMP2, SHH and BTEB) were analyzed except for $\operatorname{TR} \alpha$ and $T R \beta$, which were reported in our previous study (Lou et al., 2014a).

The tadpoles $(n=8-10)$ at stages $26,30,34,38,40,41,42,44$, and 46 were collected from the stock populations from two different sets of adults, respectively. The tadpoles were anesthetized and killed in $100 \mathrm{mg} / \mathrm{L}$ MS-222 buffered with $200 \mathrm{mg} / \mathrm{L}$ of sodium bicarbonate. Then their abdomens were opened, and intestine tissues were sampled and immediately immersed in TRIzol reagent for RNA extraction.

All animal procedures were conducted according to Regulations for the Administration of Affairs Concerning Experimental Animals (State Science and Technology Commission of the People's Republic of China, 1988).

\subsection{Choice for $\mathrm{T} 3$ induction time}

According to our previous reports (Lou et al., 2014a), TR expression was regarded as one of the molecular biomarkers for assaying TH signaling disruption in P. nigromaculatus, with the intestines of stage 27 tadpoles as test tissues. Here, we chose an appropriate time for T3 induction in the screening assay by comparing the response of TR expression for $24 \mathrm{hr}-, 48 \mathrm{hr}-$, and $72 \mathrm{hr}$-T3 induction in the intestines of stage 27 tadpoles.

Tadpoles at stage 27 from a clutch were exposed to $1 \mathrm{nmol} / \mathrm{L}$ T3 for 24-72 hr, and three replicate test beakers (12 tadpoles per beaker) were employed for each treatment group. Exposure was conducted at $24^{\circ} \mathrm{C} \pm 1^{\circ} \mathrm{C}$ under a 12 -hr light/12-hr dark cycle. Following water changes, chemical replacements were performed every $24 \mathrm{hr}$. Before changing water, four tadpoles from each test beaker (12 tadpoles) were randomly selected and anesthetized in MS-222, and then two intestine tissues were pooled into one mixed sample and immersed in TRIzol reagent for RNA extraction. TR expression was analyzed by RT-qPCR. The experiment was repeated three times using tadpoles from different sets of adults.

\subsection{Choice for $\mathrm{T} 3$ induction concentration}

To choose an appropriate T3 concentration to induce TH-gene expression, we investigated the dose-response relationship between T3 and TH-response gene expression. Tadpoles at stage 27 from a clutch were exposed to a series of concentrations of T3 $(0,0.001,0.01,0.1,1,10$, and $100 \mathrm{nmol} / \mathrm{L})$ for the chosen time for T3 induction. Expression of six TH-response genes (TR $\alpha, \mathrm{TR} \beta$, BTEB, TH/bZIP, SHH, and MMP2) was analyzed by RT-qPCR.

Three replicate test beakers (four tadpoles per beaker) were employed for each treatment group. Exposure condition and sample collection were as described above. The experiment was repeated three times using tadpoles from different sets of adults.

\subsection{Thyroid hormone signaling disrupting activity of TBBPA in P. nigromaculatus}

To validate the P. nigromaculatus screening assay established in this study, we used this assay to detect the $\mathrm{TH}$ signaling disrupting action of TBBPA, a known TH signaling disruptor. Tadpoles at stage 27 were exposed to TBBPA $(1,10,100$, and $1000 \mathrm{nmol} / \mathrm{L}$ ) in the presence or absence of the chosen concentration of T3 for the chosen time for T3 induction. The DMSO concentration was $0.001 \%(\mathrm{v} / \mathrm{v})$ in all beakers. Three replicate test beakers (four tadpoles per beaker) were employed for each treatment group. Exposure conditions and sample collection were as described above. Expression of TH-response genes (TR $\beta$, BTEB, TH/bZIP, MMP2, and SHH) was analyzed by RT-qPCR. Additionally, expression of type 3 iodothyronine deiodinase (DIO3), which was used as a molecular biomarker to assay exogenous TR agonists and antagonists in previous studies using X. laevis (Fini et al., 2012a; Nakajima et al., 2012), was also detected. The experiment was repeated three times using tadpoles from different sets of adults.

\subsection{RNA extraction and RT-qPCR}

Total RNA was isolated from intestines using TRIzol reagent following the manufacturer's instructions. RNA quality was verified by electrophoresis on ethidium bromide-stained $1 \%$ agarose gels and by A260 nm/A280 nm ratio (Nanodrop ND-1000, Nano-Drop, Wilmington, USA) in the range of 1.8-2.0. Total RNA concentration was calculated from absorbance at $260 \mathrm{~nm}$. Then first-strand cDNA was synthesized from $1 \mu \mathrm{g}$ total RNA using the Fast Quant RT Kit following the manufacturer's instructions.

To analyze TH-response gene expression levels, we conducted qPCR using SYBR Green I with the MX Real-time Polymerase Chain Reaction system (Light Cycler 480, Roche, Switzerland). Ribosomal protein L8 (rpl8) was used as a reference gene to normalize mRNA expression (Lou et al., 2014b). Specific primers are shown in Table 1. PCR conditions were as follows: $95^{\circ} \mathrm{C}$ for $15 \mathrm{~min}, 40$ cycles at $95^{\circ} \mathrm{C}$ for $10 \mathrm{sec}$, annealing at different temperatures (listed in Table 1) for $20 \mathrm{sec}$, and $72^{\circ} \mathrm{C}$ for $20 \mathrm{sec}$. Following the manufacturer's instructions, melting curves were performed to determine the specific amplification of these genes. Additionally, we determined the specificity of these primers by sequencing PCR products.

\subsection{Data analysis}

The fold change of gene expression compared to the reference was determined by the $2^{-\Delta \Delta \mathrm{Ct}}$ method (Livak and Schmittgen, 2001). Quantitative data are shown as mean \pm standard error of the mean (SEM). To identify developmental expression of candidate TH-response genes, fold-changes were calculated relative to stage 26 . Statistical differences in mRNA expression between T3 treatments and controls were assessed by one-way analysis of variance followed by Student-Newman-Keuls (SNK) post-hoc analyses (ANOVA, SPSS 16.0, USA) $(p<0.01)$. Statistical differences among TBBPA treatments and controls in the absence or presence of T3 were analyzed by two-way ANOVA 
Table 1 - Primers used for RT-qPCR and related information.

\begin{tabular}{|c|c|c|c|c|c|}
\hline Gene & Primer sequences $\left(5^{\prime}-3^{\prime}\right)$ & GenBank ID & Amplify length & Annealing temperature & PCR efficiency \\
\hline \multirow[t]{2}{*}{ rpl8 } & F: GCTGTCGACTTCGCAGAAAGGCA & KF585213 & $102 \mathrm{bp}$ & $60^{\circ} \mathrm{C}$ & $100 \%$ \\
\hline & R: ACCTGTAAGGGTCACGGAAGGCA & & & & \\
\hline \multirow[t]{2}{*}{$\mathrm{TR} \alpha$} & F: TCTCCGGGCTGCTGTGCGTTA & KC139354.1 & $114 \mathrm{bp}$ & $60^{\circ} \mathrm{C}$ & $108 \%$ \\
\hline & R: GCATCTGAGACCACCCCAAGTCCA & & & & \\
\hline \multirow[t]{2}{*}{$\mathrm{TR} \beta$} & F: GGAGGACTAGGAGTGGTATCTG & KC139355.1 & $90 \mathrm{bp}$ & $63^{\circ} \mathrm{C}$ & $107 \%$ \\
\hline & R: CAACAAGGCGACTTCGGTAT & & & & \\
\hline \multirow[t]{2}{*}{ BTEB } & F: ACACAGGCGAGAAGCAGTT & KF724718 & $145 \mathrm{bp}$ & $62^{\circ} \mathrm{C}$ & $97 \%$ \\
\hline & R: CAGATGAAGGTTGAGCTGGATC & & & & \\
\hline \multirow[t]{2}{*}{$\mathrm{TH} / \mathrm{bZIP}$} & F: GACGCAAGAACAATGAGGCT & KF724721 & $132 \mathrm{bp}$ & $62^{\circ} \mathrm{C}$ & $104 \%$ \\
\hline & R: AACGGAGAGCAAGAAGTTCAG & & & & \\
\hline \multirow[t]{2}{*}{$\mathrm{SHH}$} & F: TTACTAGGAACTCGGAGAGGTT & KF724720 & $90 \mathrm{bp}$ & $62^{\circ} \mathrm{C}$ & $98 \%$ \\
\hline & R: TGTCGGCTGCTGTGTTCT & & & & \\
\hline \multirow[t]{2}{*}{ MMP2 } & F: ACCACAGAAGACTATGACAAGG & KF724719 & $99 \mathrm{bp}$ & $60^{\circ} \mathrm{C}$ & $106 \%$ \\
\hline & R: GAAGACACAAGGAGAGCCATC & & & & \\
\hline \multirow[t]{2}{*}{ DIO3 } & F: ACGGACAGAAGCTCGACTT & SRP041632 & $144 \mathrm{bp}$ & $64^{\circ} \mathrm{C}$ & $106 \%$ \\
\hline & R: TGCCGAAGTTGACCACTAGG & & & & \\
\hline
\end{tabular}

F: forward; R: reverse; rpl8, ribosomal protein L8; TR $\alpha$, thyroid hormone receptor alpha; TR $\beta$, thyroid hormone receptor beta; BTEB, basic transcription element binding protein; TH/bZIP, TH-responsive basic leucine zipper transcription factor; SHH, sonic hedgehog; MMP2, matrix metalloproteinase 2; DIO3, type 3 iodothyronine deiodinase.
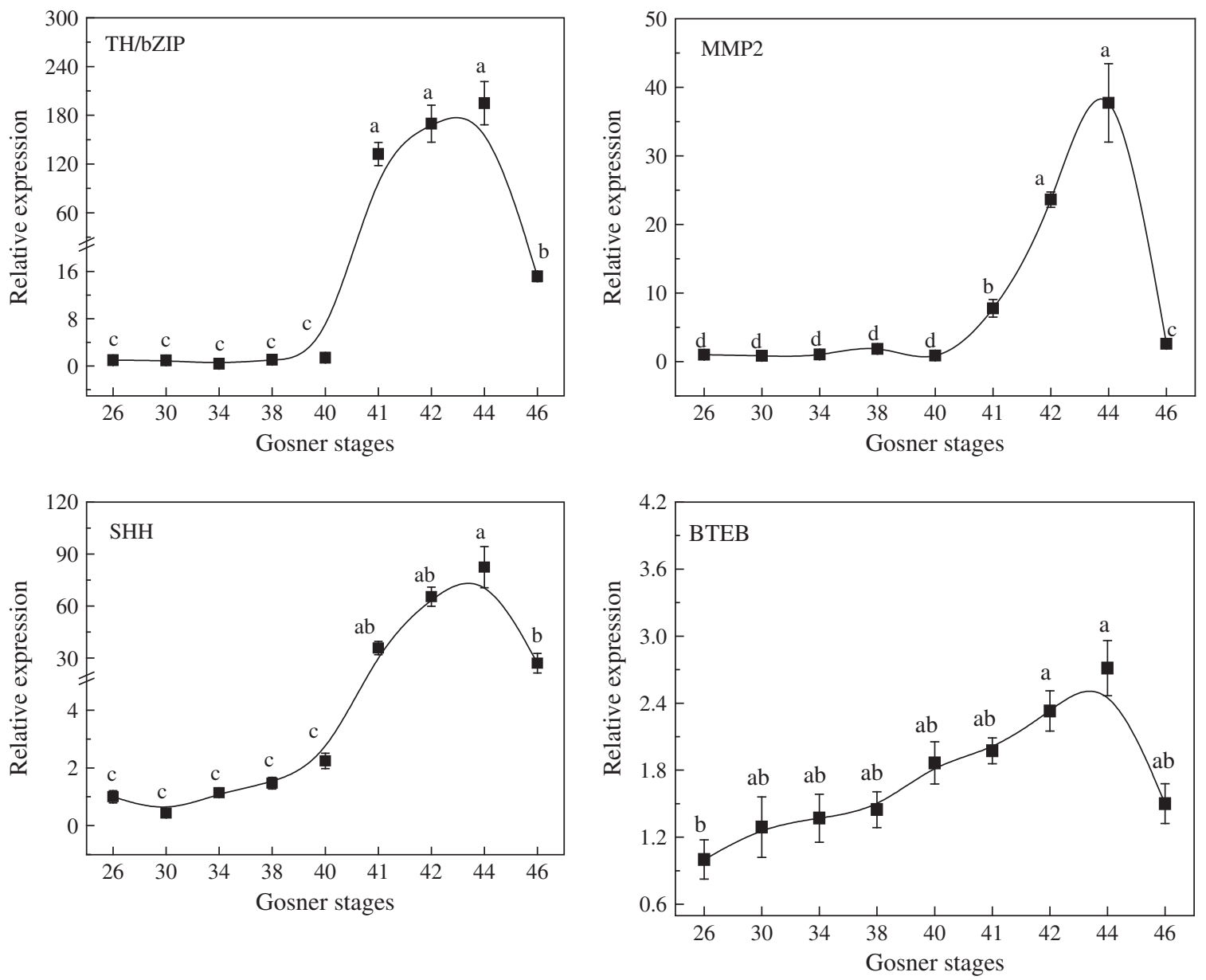

Fig. 1 - Developmental expression of candidate TH-response genes in the intestine during Pelophylax nigromaculatus metamorphosis. Data are shown as means $\pm \operatorname{SEM}(p<0.01)$, and the tadpoles are from two different sets of adults ( $n$ : $8-10)$. TH/bZIP: TH-responsive basic leucine zipper transcription factor; SHH: sonic hedgehog; MMP2: matrix metalloproteinase 2; BTEB: basic transcription element binding protein. 
followed by Duncan post-hoc analyses $(p<0.05)$. The developmental expression of candidate TH-response genes in Fig. 1 was fitted by B-spline curves (Origin 8.5, Origin Lab., Northampton, USA). The dose-response curves of TH-response genes to exogenous T3 in Fig. 3 were fitted with a sigmoidal model (Origin Lab) to derive the value of EC50.

\section{Results}

2.1. Expression changes of candidate TH-response genes in the intestine parallel changes in endogenous TH levels during metamorphosis

The expression levels of TH/bZIP were relatively low and remained stable before stage 41 , but increased sharply after stage 41 and peaked at stages $41-44$ (Fig. 1). Then, TH/bZIP expression decreased towards the end of metamorphosis (stage 46), but was still significantly higher than the levels observed before stage $40(p<0.01)$. Similarly, SHH mRNA expression during metamorphosis exhibited a parallel profile with TH/bZIP, although the fold change of SHH expression at metamorphic climax relative to stage 26 was smaller than that of TH/bZIP. Like TH/bZIP and SHH, MMP2 peaked around stages 42-44 and declined towards stage 46 . However, the decline of MMP2 mRNA levels towards stage 46 was so dramatic that it returned to the level at stage 26. Different from the other three genes, changes in BTEB mRNA levels were not dramatic during the whole metamorphosis. Compared with the mRNA level at stage 26, BTEB expression displayed a slowly increasing trend with development, peaked at stage 42-44, and decreased at stage 46 .

Overall, TH/bZIP, SHH and MMP2 as well as TRs in the intestine displayed roughly similar expression profiles during $P$. nigromaculatus metamorphosis, with a similar trend of BTEB expression (Lou et al., 2014a). The expression profiles of these genes parallel changes in endogenous TH levels, which remain low at premetamorphic and most prometamorphic stages, increase beginning in late prometamorphic stages, peak at the metamorphic climax, and decline towards the end of metamorphosis (Ge et al., 2014; Lou et al., 2014a). It is suggested that changes in TH-response gene expression levels reflect to some degree the responsiveness of TH-response genes to endogenous TH during P. nigromaculatus metamorphosis. The peak levels of TH/bZIP, SHH, MMP2, and BTEB expression were about 195-, 82-, 38-, and 3-fold the levels at stage 26 , respectively. The data demonstrate that $\mathrm{TH} /$ bZIP expression has higher responsiveness to endogenous T3, with lower responsiveness for BTEB expression.

\subsection{Determination of $\mathrm{T} 3$ induction time ( $48 \mathrm{hr})$}

To determine an appropriate time for $\mathrm{T} 3$ induction in the screening assay, we compared the effects of $24 \mathrm{hr}-, 48 \mathrm{hr}-$, and $72 \mathrm{hr}-\mathrm{T} 3$ induction on expression of $\mathrm{TR} \beta$ and $\mathrm{TR} \alpha$, as the representatives of $\mathrm{TH}$-response genes, in intestines from stage 27 tadpoles. It was found that T3 significantly up-regulated TR $\beta$ transcriptional levels in intestines, with no significant difference among $24 \mathrm{hr}-, 48 \mathrm{hr}-$, and $72 \mathrm{hr}$-T3 induction times (Fig. 2). $\mathrm{T} 3$ exposure for $24 \mathrm{hr}$ and $48 \mathrm{hr}$ also induced TR $\alpha$ expression, whereas $72 \mathrm{hr}$-T3 induction was noneffective (Fig. 2). Based on these observations and a consideration of the time for test chemicals to concentrate in tadpoles, we chose $48 \mathrm{hr}$-T3 treatment to induce TH-response gene expression in the screening assay.

2.3. Dose-response curves between exogenous T3 and THresponse gene expression and determination of $\mathrm{T} 3$ induction concentration $(0.2 \mathrm{nmol} / \mathrm{L})$

To determine an appropriate concentration for $\mathrm{T} 3$ induction in the screening assay, we investigated the responsiveness of the
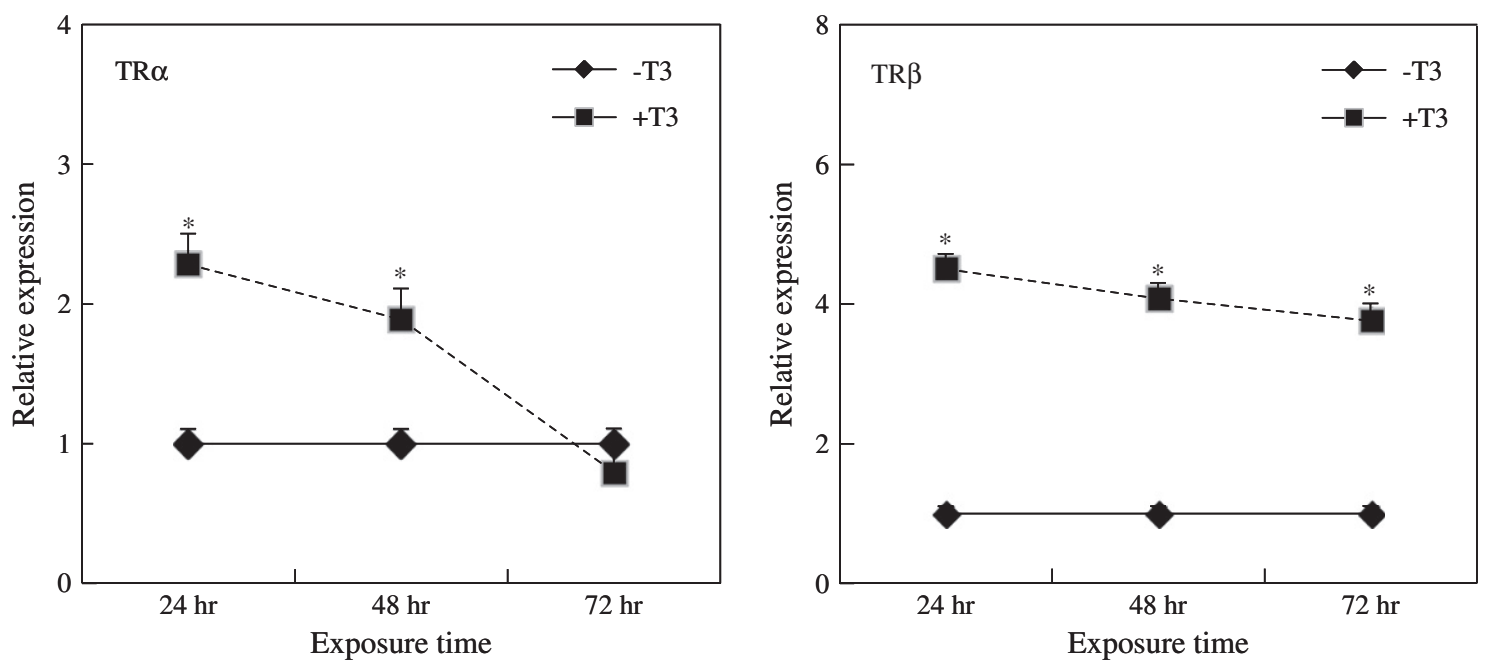

Fig. 2 - Thyroid hormone receptor (TR $\alpha$ and TR $\beta$ ) expression in the intestines of Gosner stage 27 Pelophylax nigromaculatus tadpoles following T3 exposure for 24-72 hr. Data are shown as means \pm SEM ( $n=12,24$ tadpoles). Significant differences between T3 treatment groups and the control were indicated by ${ }^{*} p<0.01$. All experiments were repeated three times with similar results. Here we show the combined data from two experiments because the tadpoles displayed higher sensitiveness to T3 in another experiment. 
six candidate TH-response genes to $48 \mathrm{hr}$-T3 treatment $(0.001-$ $100 \mathrm{nmol} / \mathrm{L}$ ) in the intestines from stage $27 \mathrm{P}$. nigromaculatus tadpoles. Fig. 3 shows the dose-response curves between T3 concentrations and the expression levels of TR $\alpha, \mathrm{TR} \beta, \mathrm{BTEB}, \mathrm{TH} /$ bZIP, SHH, and MMP2. T3 up-regulated expression levels of these genes compared with the control, with $0.01 \mathrm{nmol} / \mathrm{L}$ as the lowest observed effective concentration (LOEC) for TR $\alpha$, TR $\beta$, $\mathrm{BTEB}$, and MMP2 and $0.001 \mathrm{nmol} / \mathrm{L}$ for $\mathrm{TH} / \mathrm{bZIP}$ and $\mathrm{SHH}$ (Table 2). With increasing T3 concentrations, the agonistic actions of T3 on gene expression increased. TR $\beta$ and BTEB
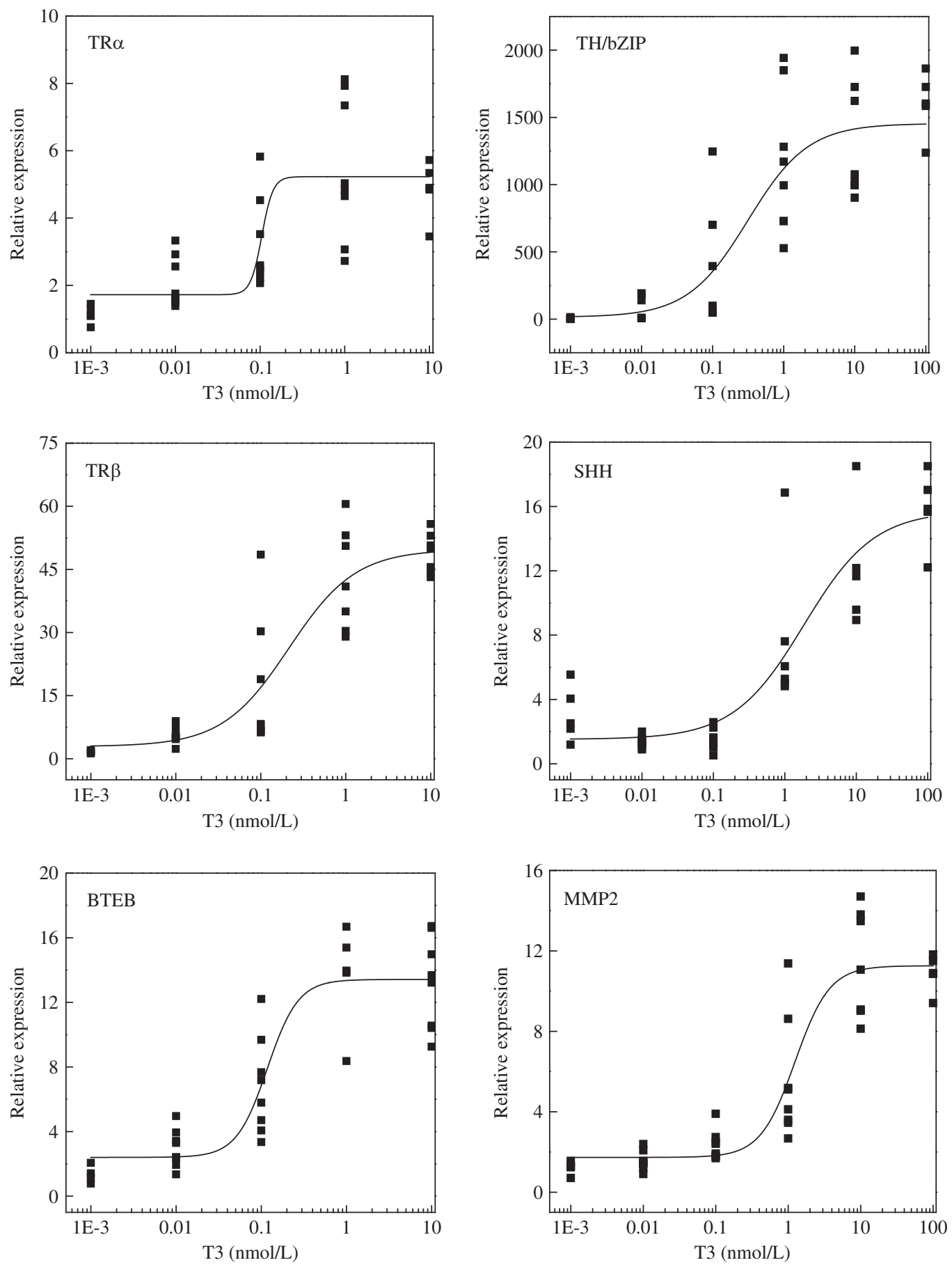

Fig. 3 - Dose-response curves between T3 concentrations and TH-response gene expression in the intestines of Pelophylax nigromaculatus tadpoles at Gosner stage 27. All experiments were repeated three times using tadpoles from different sets of adults with similar results. Here we show the combined data from two experiments $(n=12)$ because the tadpoles displayed higher sensitiveness to T3 in another experiment. TR $\alpha$ : thyroid hormone receptor alpha; TR $\beta$ : thyroid hormone receptor beta; BTEB: basic transcription element binding protein; TH/bZIP: TH-responsive basic leucine zipper transcription factor; SHH: sonic hedgehog; MMP2: matrix metalloproteinase 2. 
Table 2-T3 induction on TH-response gene expression in the intestines of Gosner stage 27 Pelophylax nigromaculatus tadpoles.

\begin{tabular}{|c|c|c|c|c|c|c|}
\hline & $\mathrm{TR} \alpha$ & TR $\beta$ & BTEB & $\mathrm{TH} / \mathrm{bZIP}$ & $\mathrm{SHH}$ & MMP2 \\
\hline LOEC (nmol/L) & 0.01 & 0.01 & 0.01 & 0.001 & 0.001 & 0.01 \\
\hline HIE (fold) & $3.952 \pm 0.558$ & $48.87 \pm 1.802$ & $13.18 \pm 1.806$ & $1608 \pm 189.8$ & $15.91 \pm 1.901$ & $10.91 \pm 1.312$ \\
\hline EC50 (nmol/L) & - & $0.215 \pm 0.087$ & $0.118 \pm 0.068$ & $0.291 \pm 0.147$ & $1.075 \pm 0.426$ & $1.299 \pm 0.427$ \\
\hline
\end{tabular}

expression appeared to reach plateaus at 1-10 $\mathrm{nmol} / \mathrm{L}$, whereas the plateaus of TH/bZIP, SHH, MMP2 expression occurred at concentrations higher than $10 \mathrm{nmol} / \mathrm{L}$. The highest inductive effects (HIE) of T3 on TR $\alpha$, TR $\beta$, BTEB, TH/bZIP, SHH, and MMP2 were about 4-, 49-, 13-, 1600-, 16-, and 11-fold of the control, respectively. The dose-response curves between $\mathrm{T} 3$ and the expression levels of these genes (except TR $\alpha$ ) were well fitted with a sigmoidal model. The effective concentrations (EC50) of T3 for expression of the other five genes ranged from 0.118 to $1.229 \mathrm{nmol} / \mathrm{L}$. Given that T3 induction on TR $\alpha$ expression was very weak, we chose TR $\beta, B T E B, T H / b Z I P, S H H$, and MMP2 as molecular endpoints for the P. nigromaculatus screening assay. Based on the LOECs and EC50 values for these TH-response genes, we chose $0.2 \mathrm{nmol} / \mathrm{L}$ T3 to induce gene expression in the P. nigromaculatus screening assay.

Taken together, we have established a P. nigromaculatus screening assay for TH signaling disruption, in which tadpoles at stage 27 are treated with a test chemical in the presence or absence of $0.2 \mathrm{nmol} / \mathrm{L}$ T3 for $48 \mathrm{hr}$. By investigating the effects of the test chemical on TR $\beta$, BTEB, TH/bZIP, SHH, and MMP2 expression in tadpole intestines in the presence or absence of $\mathrm{T} 3$, the chemical is determined as a TH signaling agonist or antagonist or noneffective factor.

2.4. TBBPA exhibits TH signaling disrupting activity in the $P$. nigromaculatus screening assay

Using the P. nigromaculatus screening assay, we detected the $\mathrm{TH}$ signaling disrupting activity of TBBPA in order to validate the screening assay. In the absence of T3, $1000 \mathrm{nmol} / \mathrm{L}$ TBBPA promoted TH/bZIP and MMP2 expression, with no obvious effect on the other genes (Fig. 4). The data suggest that TBBPA alone had a weak agonistic action on $\mathrm{TH}$ signaling. In the presence of $0.2 \mathrm{nmol} / \mathrm{L} \mathrm{T3}, 1 \mathrm{nmol} / \mathrm{L}$ TBBPA significantly promoted T3-induced expression of all the TH-response genes compared with T3 treatment $(p<0.05)$. With increasing TBBPA concentrations, however, the expression levels of these genes decreased. TBBPA at $10 \mathrm{nmol} / \mathrm{L}$ inhibited or had no effect on T3-induced gene expression. Higher concentrations (100-1000 $\mathrm{nmol} / \mathrm{L})$ of TBBPA inhibited the T3-induced expression of all genes tested (Fig. 4).

In the $P$. nigromaculatus screening assay, in the presence of T3, lower concentrations of TBBPA had agonistic effects on TH-response gene expression, whereas higher concentrations had antagonistic effects, exhibiting a non-monotonic doseresponse manner. In contrast to TBBPA plus T3 treatment, TBBPA alone may have a weak agonistic action on TH signaling.

\section{Discussion}

$\mathrm{X}$. laevis has been most commonly used to study TH signaling disruption of chemicals (Crump et al., 2002; Fini et al., 2007; Zhang et al., 2014). However, it is necessary to develop some other assays using native species, considering species differences and the accessibility of test species. Recently, we presented the utilizability of $P$. nigromaculatus as a test species for assaying the TH signaling disrupting activity of chemicals (Lou et al., 2014a). In particular, the TR expression in P. nigromaculatus intestine was demonstrated to be sensitive to TH induction, and can be used as a molecular endpoint for screening TH signaling disrupting effects (Lou et al., 2014a). This study aimed to develop a P. nigromaculatus screening assay for TH signaling disruption using additional TH-response genes as molecular markers. We chose four candidate TH-response genes, including TH/bZIP, SHH, MMP2 and BTEB, which have been used as molecular markers to study TH signaling disruption in X. laevis (Fini et al., 2012a; Heimeier et al., 2009; Zhang et al., 2014). The expression changes of the four candidate genes in P. nigromaculatus intestines were found to parallel endogenous TH levels during metamorphosis, which is consistent with previous observations in X. laevis (Heimeier et al., 2010). The peak levels of TH/bZIP, SHH, MMP2 and BTEB expression at metamorphic climax were about 195-, 82-, 38- and 3 -fold the levels at stage 26 , respectively (Fig. 1). The data demonstrate that these genes are responsive to endogenous T3 in P. nigromaculatus, and their expression is suitable for use as molecular endpoints for assaying TH signaling disruption.

In accordance with the response of these genes to endogenous $\mathrm{TH}$, the dose-response curves between exogenous $\mathrm{T} 3$ and TH-response gene expression further demonstrate the high responsiveness of TR $\beta, \mathrm{BTEB}, \mathrm{MMP} 2, \mathrm{SHH}$ and $\mathrm{TH} / \mathrm{bZIP}$ to exogenous T3 in P. nigromaculatus intestines, with low responsiveness for $\mathrm{TR} \alpha$ (Fig. 3). Similarly, higher responsiveness of TR $\beta$, BTEB, MMP2, SHH and TH/bZIP than TR $\alpha$ to TH was reported previously in premetamorphic tadpoles in $\mathrm{X}$. laevis and Rana catesbeiana (Heimeier et al., 2009; Stolow and Shi, 1995; Veldhoen et al., 2014b; Zhang et al., 2014). To ensure high sensitivity for the nigromaculatus screening assay, thus, we chose TR $\beta$, BTEB, TH/bZIP, SHH, and MMP2 but not TR $\alpha$ as molecular endpoints. In the literature, several screening assays for TH signaling disruption using TH-response gene expression or TH-regulated reporter gene expression as endpoints were reported previously (Table 3). We compared the sensitivity of molecular endpoints for the P. nigromaculatus screening assay 

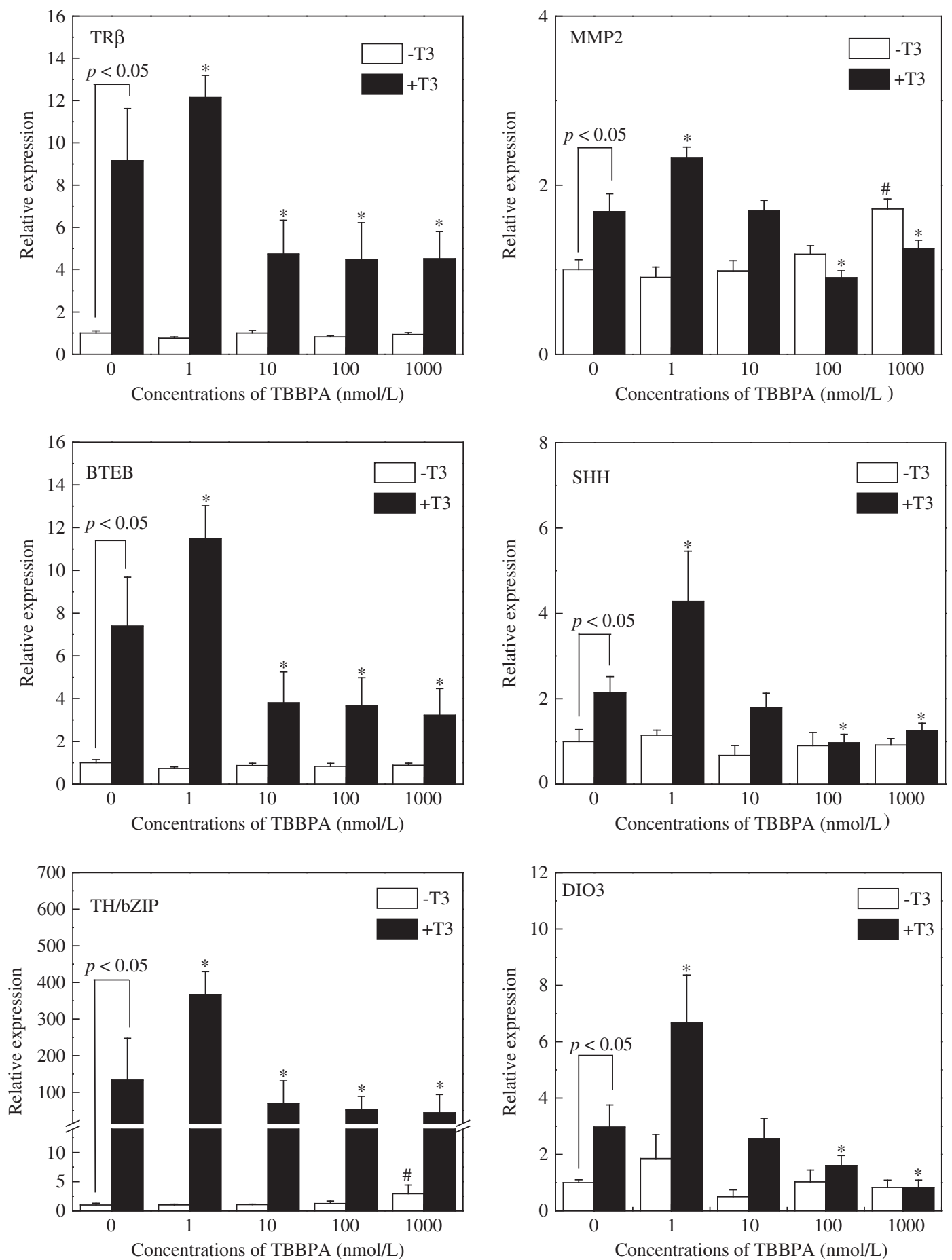

Fig. 4 - Effects of TBBPA on TH-response gene expression in the intestines of Gosner stage 27 Pelophylax nigromaculatus tadpoles following $48 \mathrm{hr}$-exposure to tetrabromobisphenol A (TBBPA) in the absence or presence of $0.2 \mathrm{nmol} / \mathrm{L}$ T3. All experiments were repeated three times using tadpoles from different sets of adults with similar results. Here we show the combined data from two experiments $(n=12)$ because the tadpoles displayed higher sensitiveness to T3 in another experiment. Data are shown as mean \pm SEM. \# and * indicate significant differences between TBBPA treatment and the control, and between TBBPA + T3 treatment and T3 treatment, respectively $(p<0.05)$. TR $\beta$ : thyroid hormone receptor beta; BTEB: basic transcription element binding protein; TH/bZIP: TH-responsive basic leucine zipper transcription factor; MMP2: matrix metalloproteinase 2; SHH: sonic hedgehog; DIO3: type 3 iodothyronine deiodinase.

with previously reported assays according to LOEC and EC50 values of T3 for gene expression. Turque et al. (2005) constructed a TH/bZIP-GFP reporter system in X. laevis tadpoles, which can detect significant transcription up-regulated by $0.001 \mathrm{nmol} / \mathrm{L}$ T3. In $\mathrm{P}$. nigromaculatus intestines, $\mathrm{TH} / \mathrm{bZIP}$ and $\mathrm{SHH}$ expression induced by $0.001 \mathrm{nmol} / \mathrm{L}$ T3 was also found. That is, molecular 
Table 3 - Comparison of sensitivity to T3 between our study and other assays in the literature.

\begin{tabular}{|c|c|c|c|c|c|}
\hline \multicolumn{2}{|r|}{ Assay organism } & \multicolumn{3}{|c|}{ T3 (nmol/L) } & \multirow[t]{2}{*}{ Reference } \\
\hline & & CR & LOEC & EC50 & \\
\hline \multirow[t]{3}{*}{ In vivo } & P. nigromaculatus intestine & $0.001-100$ & $0.001-0.01$ & $0.118-1.299$ & This study \\
\hline & X. laevis caudal muscle & ND & 0.001 & ND & Turque et al. (2005) \\
\hline & R. pipiens brain & $0.05-50$ & 50 & ND & Hogan et al. (2007) \\
\hline \multirow[t]{15}{*}{ In vitro } & MtT/E-2-rat TR $\alpha$ or $\beta$ & $0.001-10$ & 0.01 & ND & Matsubara et al. (2012) \\
\hline & Rat GH3.TRE-Luc & $0.001-100$ & 0.01 & 0.1 & Freitas et al. (2011) \\
\hline & HEK293-vertebrate TRs & $0.001-100$ & 0.01 & 0.243 & Oka et al. (2012) \\
\hline & Rat PC-DR-LUC & $0.03-10$ & 0.03 & 0.18 & Jugan et al. (2007) \\
\hline & CV-pGal4-LTR $\beta$ & $0.1-10000$ & 0.1 & ND & Hu et al. (2013) \\
\hline & HepG2-human TRs & $0.01-10000$ & 0.1 & 1.2 & Hofmann et al. (2009) \\
\hline & Yeast-human TR $\beta$-SRC-1 & $0.1-10000$ & 0.2 & 1.5 & Shiizaki et al. (2010) \\
\hline & GH3 cells-DIO1 & $0.5-100$ & 0.5 & ND & Davey et al. (2008) \\
\hline & GH3.TRE-Luc high-throughput & $0.0003-4600$ & ND & 0.33 & Freitas et al. (2014) \\
\hline & $\mathrm{X}$. laevis cell-X. laevis TR & $0.1-1000$ & ND & 10 & Furlow et al. (2004) \\
\hline & CV-1 cell-TR $\beta$ & $0.01-1000$ & ND & 11.3 & Sun et al. (2009) \\
\hline & Yeast-human TR-GRIP1 & $0.05-1000$ & 3 & 26 & Li et al. (2014) \\
\hline & Yeast-human TR $\alpha$ & $0.1-1000$ & ND & 55 & Terasaki et al. (2011) \\
\hline & Yeast-human TR-GRIP1 & $0.01-5000$ & ND & 110 & Li et al. (2008) \\
\hline & CHO-human TR $\alpha$ & $0.01-10000$ & 10 & ND & Kitamura et al. (2005) \\
\hline
\end{tabular}

endpoints in P. nigromaculatus display a comparable sensitivity to the assay of Turque et al. However, the LOEC value of T3 in Rana pipiens reached up to $50 \mathrm{nmol} / \mathrm{L}$ (Hogan et al., 2007). In TH-regulated transcription assays in vitro, the LOEC and EC50 values of T3 varied in the range of $0.01-10 \mathrm{nmol} / \mathrm{L}$ and 0.01-110 nmol/L, respectively. In our study, the LOEC and EC50 values of T3 for the molecular endpoints in $P$. nigromaculatus were $0.001-0.01 \mathrm{nmol} / \mathrm{L}$ and $0.118-1.229 \mathrm{nmol} / \mathrm{L}$, respectively. These data show that the molecular endpoints in $P$. nigromaculatus intestines in our study are comparable to or more sensitive than previously reported assays for detecting $\mathrm{TH}$ signaling disrupting activity.

Following determination of molecular markers and T3 induction time and concentration, we validated the $P$. nigromaculatus screening assay using TBBPA as a model TH signaling disruptor. In previous studies, TBBPA alone generally exhibited a weak TH stimulatory activity in the absence of $\mathrm{TH}$, with a TH antagonistic activity in the presence of TH (Fini et al., 2012b; Jagnytsch et al., 2006; Zhang et al., 2014), as shown in Table 4. In accordance with previous reports, we found that $1000 \mathrm{nmol} / \mathrm{L}$ TBBPA alone weakly activated intestinal TH-response gene expression (Fig. 4), whereas 10$1000 \mathrm{nmol} / \mathrm{L}$ TBBPA exhibited a TH antagonistic action in the presence of T3, showing that the $P$. nigromaculatus screening assay we established is effective for detecting the TH signaling disrupting activity of TBBPA. Additionally, we found that in contrast to the results for higher concentrations, $1 \mathrm{nmol} / \mathrm{L}$ TBBPA promoted $\mathrm{TH}$-induced gene expression in the presence of T3, showing a non-monotonic dose-response manner (Fig. 4). Our recent study concerning $X$. laevis also reported a non-monotonic dose-response manner of TBBPA in affecting TH-response gene expression, with 10-100 nmol/L TBBPA as a $\mathrm{TH}$ agonist and $500-1000 \mathrm{nmol} / \mathrm{L}$ as a TH antagonist in the presence of T3 (Zhang et al., 2014). In accordance with the agonistic effect on T3 induction of $1 \mathrm{nmol} / \mathrm{L}$ TBBPA in our study, Veldhoen et al. (2006) also found $10 \mathrm{nmol} / \mathrm{L}$ TBBPA increased gel B transcript in the presence of T3 in the tail from Pseudacris regilla tadpole, and $100 \mathrm{nmol} / \mathrm{L}$ TBBPA promoted T3-induced TR $\alpha$ expression in the brain. In addition, one in vitro study using GH3.TRE-Luc cell lines also revealed a non-monotonic dose-dependent TH signaling disrupting action of TBBPA ranging from $100 \mathrm{nmol} / \mathrm{L}-10 \mu \mathrm{mol} / \mathrm{L}$ in the presence of T3 (Freitas et al., 2011). However, other in vitro reporter gene assays could not detect non-monotonic dose-dependent effects of TBBPA on TH signaling, even when a wide concentration range of TBBPA was tested (Hofmann et al., 2009; Kudo et al., 2006; Oka et al., 2012). It is known that non-monotonic dose-response for endocrine disrupting chemicals is observed frequently (Beausoleil et al., 2013; Vandenberg, 2014). Our study strongly demonstrates a non-monotonic dose-response of TBBPA in terms of $\mathrm{TH}$ signaling disrupting activity. Comparing our assay and other in vivo amphibian assays in the literature (Table 4), the LOECs of TBBPA for TH signaling disrupting effects in vivo amphibian assays were close to or higher than those in our study, demonstrating that our assay has more or comparable sensitivity for detecting TH signaling disruption compared with other in vivo amphibian assays (Fini et al., 2012a; Veldhoen et al., 2006; Zhang et al., 2014). Compared with in vitro assays (Table 4), in which the LOECs of TBBPA for TH signaling disrupting effects are higher by 2-3 orders than those in our assay, the sensitivity of our assay is superior. Possibly, the fact that the biphasic effects of TBBPA on TH signaling occurring in in vivo assays were not detected in in vitro assays is due to their low sensitivity. In particular, the LOEC of TBBPA ( $1 \mathrm{nmol} / \mathrm{L}, 0.54 \mu \mathrm{g} / \mathrm{L})$ in our study is in the range of environmentally relevant concentrations, which generally range from $\mathrm{pg} / \mathrm{L}$ to several $\mu \mathrm{g} / \mathrm{L}$ levels in surface water (He et al., 2013; Labadie et al., 2010; Yang et al., 2012). Taken together, the $P$. nigromaculatus screening assay we established is capable of detecting TH signaling disrupting activity of environmental chemicals with high sensitivity. Given that the P. nigromaculatus population is declining in East 
Table 4 - Comparison of TH signaling disrupting activity of TBBPA between in our study and other assays in the literature.

\begin{tabular}{|c|c|c|c|c|c|c|}
\hline \multicolumn{2}{|c|}{ Assay organism } & \multicolumn{4}{|c|}{ TBВPA $(\mu \mathrm{mol} / \mathrm{L})$} & \multirow[t]{2}{*}{ Reference } \\
\hline & & LOEC & CR (Toxicity) & $-\mathrm{T} 3$ & $+\mathrm{T} 3$ & \\
\hline \multirow[t]{6}{*}{ In vivo } & P. nigromaculatus intestine & 0.001 & $0.001-1$ (ND) & $1 \uparrow$ & $0.001 \uparrow$ & This study \\
\hline & & & & & $0.01-1 \downarrow$ & \\
\hline & $X$. laevis intestine & 0.01 & $0.01-1$ (ND) & $0.01-1 \uparrow$ & $\begin{array}{l}0.01-0.1 \uparrow \downarrow \\
0.1-1 \downarrow\end{array}$ & Zhang et al. (2014) \\
\hline & P. regilla tail and brain & 0.01 & $0.01-0.1$ (ND) & $0.01-0.1 \uparrow$ & $\begin{array}{l}0.01 \uparrow \\
0.1 \uparrow \downarrow\end{array}$ & Veldhoen et al. (2006) \\
\hline & $X$. laevis head & 0.184 & $0.184-0.920(\mathrm{ND})$ & $0.920 \uparrow$ & $0.184-0.920 \downarrow$ & Jagnytsch et al. (2006) \\
\hline & $X$. laevis brain & 1 & 1 (ND) & $1 \uparrow$ & ND & Fini et al. (2012a) \\
\hline \multirow[t]{14}{*}{ In vitro } & Rat GH3.TRE-Luc & 0.1 & $0.1-100$ & ND & $0.1-5 \uparrow$ & Freitas et al. (2011) \\
\hline & & & $(>10)$ & & $5-10 \downarrow$ & \\
\hline & X. laevis-TRE-Luc & 0.1 & $\begin{array}{l}0.01-16 \\
(>4)\end{array}$ & $0.1-1 \uparrow$ & $0.1-1 \downarrow$ & Kudo et al. (2006) \\
\hline & Yeast-human TR $\alpha$ & 1 & $\begin{array}{l}0.001-100 \\
(>20)\end{array}$ & $1 \uparrow$ & $4 \downarrow$ & Terasaki et al. (2011) \\
\hline & HepG2-human TRs & 1 & $\begin{array}{l}0.001-100 \\
(>10)\end{array}$ & $1-10 \uparrow$ & $1-10 \downarrow$ & Hofmann et al. (2009) \\
\hline & MtT/E-2-rat TR $\alpha$ or $\beta$ & 1 & $1-10(\mathrm{ND})$ & ND & $1-10 \downarrow$ & Matsubara et al. (2012) \\
\hline & Yeast-human TR $\beta$-SRC-1 & 1 & $\begin{array}{l}0.001-100 \\
(\geq 5)\end{array}$ & $1-5 \uparrow$ & ND & Shiizaki et al. (2010) \\
\hline & HeLa cell-TR $\alpha$ LBD & 3 & 1-10 (ND) & $3-10 \uparrow$ & $3-10 \downarrow$ & Fini et al. (2012b) \\
\hline & CHO-human TR $\alpha$ & 3 & $\begin{array}{l}0.01-100 \\
(>50)\end{array}$ & $10 \uparrow$ & $3-50 \downarrow$ & Kitamura et al. (2005) \\
\hline & Rat PC-DR-LUC & 10 & $\begin{array}{l}10-100 \\
(>100)\end{array}$ & $\begin{array}{l}10-60 \uparrow \\
60-100 \downarrow\end{array}$ & $20-100 \downarrow$ & Jugan et al. (2007) \\
\hline & CV-1 cell-TR $\beta$ & $1<$ & $\begin{array}{l}1-100 \\
(>100)\end{array}$ & ND & $30<$ EC50 $\downarrow$ & Sun et al. (2009) \\
\hline & HEK293-vertebrat-e TRs & 10 & $\begin{array}{l}0.01-100 \\
(>10)\end{array}$ & ND & $10 \downarrow$ & Oka et al. (2012) \\
\hline & Yeast-human TR-GRIP1 & ND & ND & ND & $0.7(E C 20) \downarrow$ & Li et al. (2008) \\
\hline & Cultured X. laevis tail & $1<$ & $0.010-1$ (ND) & - & ND & Hinther et al. (2010) \\
\hline
\end{tabular}

Asia (Dai et al., 2011; IUCN, 2014), the use of P. nigromaculatus as an alternate test species for $X$. laevis is very helpful for identifying the $\mathrm{TH}$ signaling disrupting effects of chemicals on native frogs.

\section{Conclusions}

We established a 48 hr-assay for TH signaling disruption using TH-response gene expression as endpoints in P. nigromaculatus, which can detect the agonistic activity of $0.001 \mathrm{nmol} / \mathrm{L} \mathrm{T3}$. In further validation of the assay, we found $\mathrm{TH}$ agonistic activity of TBBPA in the absence of $\mathrm{TH}$ and $\mathrm{TH}$ antagonistic activity in the presence of $\mathrm{TH}$, which was reported in previous studies. Moreover, this assay detected a non-monotonic dose-response of TBBPA in disrupting TH signaling over a wide concentration range, including low concentrations. These results show that the $P$. nigromaculatus screening assay we established is suitable for detecting $\mathrm{TH}$ signaling disrupting activity of environmental chemicals with high sensitivity.

\section{Acknowledgments}

This work was supported by grants from the Hi-Tech Research and Development Program of China (No. 2012AA06A302), the
Strategic Priority Research Program of the Chinese Academy of Sciences (Nos. XDB14040102, YSW2013A01), and the National Natural Science Foundation of China (No. 21377153).

\section{R E F E R E N C E S}

Astapova, I., Hollenberg, A.N., 2013. The in vivo role of nuclear receptor corepressors in thyroid hormone action. Biochim. Biophys. Acta 1830 (7), 3876-3881.

Beausoleil, C., Ormsby, J.-N., Gies, A., Hass, U., Heindel, J.J., Holmer, M.L., et al., 2013. Low dose effects and nonmonotonic dose responses for endocrine active chemicals: Science to practice workshop: workshop summary. Chemosphere 93 (6), 847-856.

Boas, M., Feldt-Rasmussen, U., Main, K.M., 2012. Thyroid effects of endocrine disrupting chemicals. Mol. Cell. Endocrinol. 355 (2), 240-248.

Coady, K., Marino, T., Thomas, J., Currie, R., Hancock, G., Crofoot, J., et al., 2010. Evaluation of the amphibian metamorphosis assay: exposure to the goitrogen methimazole and the endogenous thyroid hormone L-thyroxine. Environ. Toxicol. Chem. 29 (4), 869-880.

Crump, D., Werry, K., Veldhoen, N., Van Aggelen, G., Helbing, C.C., 2002. Exposure to the herbicide acetochlor alters thyroid hormone-dependent gene expression and metamorphosis in Xenopus laevis. Environ. Health Perspect. 110 (12), 1199-1205. 
Dai, J.H., Ma, J.Y., Xu, L.L., Wei, Y.Q., Gu, Y.F., Zhou, K.Y., 2011. Declines of farm land and pond frogs in thirteen provinces in China. J. Nanjing Normal Univ. 34 (1), 80-85.

Davey, J.C., Nomikos, A.P., Wungjiranirun, M., Sherman, J.R., Ingram, L., Batki, C., et al., 2008. Arsenic as an endocrine disruptor: arsenic disrupts retinoic acid receptor- and thyroid hormone receptor-mediated gene regulation and thyroid hormone-mediated amphibian tail metamorphosis. Environ. Health Perspect. 116 (2), 165-172.

Fini, J.B., Le Mevel, S., Turque, N., Palmier, K., Zalko, D., Cravedi, J.P., et al., 2007. An in vivo multiwell-based fluorescent screen for monitoring vertebrate thyroid hormone disruption. Environ. Sci. Technol. 41 (16), 5908-5914.

Fini, J.B., Le Mevel, S., Palmier, K., Darras, V.M., Punzon, I., Richardson, S.J., et al., 2012a. Thyroid hormone signaling in the Xenopus laevis embryo is functional and susceptible to endocrine disruption. Endocrinology 153 (10), 5068-5081.

Fini, J.B., Riu, A., Debrauwer, L., Hillenweck, A., Le Mevel, S., Chevolleau, S., et al., 2012b. Parallel biotransformation of tetrabromobisphenol A in Xenopus laevis and mammals: Xenopus as a model for endocrine perturbation studies. Toxicol. Sci. 125 (2), 359-367.

Freitas, J., Cano, P., Craig-Veit, C., Goodson, M.L., Furlow, J.D., Murk, A.J., 2011. Detection of thyroid hormone receptor disruptors by a novel stable in vitro reporter gene assay. Toxicol. in Vitro 25 (1), 257-266.

Freitas, J., Miller, N., Mengeling, B.J., Xia, M., Huang, R., Houck, K., et al., 2014. Identification of thyroid hormone receptor active compounds using a quantitative high-throughput screening platform. Curr. Chem. Genomics Transl. Med. 7 (8), 36-46.

Freytag, R.E., Hullinghorst, R.L., Hunter, G.W., Ritchie, L.S., 1953. Comparison of Xenopus Laevis and Rana nigromaculata as test animals for the determination of pregnancy. J. Lab. Clin. Med. 42 (4), 646-654.

Furlow, J.D., Yang, H.Y., Hsu, M., Lim, W., Ermio, D.J., Chiellini, G., et al., 2004. Induction of larval tissue resorption in Xenopus laevis tadpoles by the thyroid hormone receptor agonist GC-1. J. Biol. Chem. 279 (25), 26555-26562.

Ge, Y.N., Li, Y.Y., Zhang, Y.F., Lou, Q.Q., Zhao, Y.X., Qin, Z.F., 2014. The development and thyroid hormone levels of thyroid gland during Rana nigromaculata metamorphosis. Acta Hydrobiol. Sin. 38 (4), 714-719.

Gosner, K.L., 1960. A simplified table for staging anuran embryos and larvae with notes on identification. Herpetologica 16 (3), 183-190.

Hammond, S.A., Veldhoen, N., Kobylarz, M., Webber, N.R., Jordan, J., Rehaume, V., et al., 2013. Characterization of gene expression endpoints during postembryonic development of the northern green frog (Rana clamitans melanota). Zool. Sci. 30 (5), 392-401.

Hasebe, T., Buchholz, D.R., Shi, Y.B., Ishizuya-Oka, A., 2011. Epithelial-connective tissue interactions induced by thyroid hormone receptor are essential for adult stem cell development in the Xenopus laevis intestine. Stem Cells 29 (1), 154-161.

He, M.J., Luo, X.J., Yu, L.H., Wu, J.P., Chen, S.J., Mai, B.X., 2013. Diasteroisomer and enantiomer-specific profiles of hexabromocyclododecane and tetrabromobisphenol $\mathrm{A}$ in an aquatic environment in a highly industrialized area, South China: vertical profile, phase partition, and bioaccumulation. Environ. Pollut. 179, 105-110.

Heimeier, R.A., Das, B., Buchholz, D.R., Shi, Y.B., 2009. The xenoestrogen bisphenol A inhibits postembryonic vertebrate development by antagonizing gene regulation by thyroid hormone. Endocrinology 150 (6), 2964-2973.

Heimeier, R.A., Das, B., Buchholz, D.R., Fiorentino, M., Shi, Y.B., 2010. Studies on Xenopus laevis intestine reveal biological pathways underlying vertebrate gut adaptation from embryo to adult. Genome Biol. 11 (5), R55. http://dx.doi.org/10.1186/ gb-2010-11-5-r55.

Helbing, C.C., Ovaska, K., Ji, L., 2006. Evaluation of the effect of acetochlor on thyroid hormone receptor gene expression in the brain and behavior of Rana catesbeiana tadpoles. Aquat. Toxicol. 80 (1), 42-51.

Hinther, A., Domanski, D., Vawda, S., Helbing, C.C., 2010. C-fin: a cultured frog tadpole tail fin biopsy approach for detection of thyroid hormone-disrupting chemicals. Environ. Toxicol. Chem. 29 (2), 380-388.

Hofmann, P.J., Schomburg, L., Köhrle, J., 2009. Interference of endocrine disrupters with thyroid hormone receptordependent transactivation. Toxicol. Sci. 110 (1), 125-137.

Hogan, N.S., Crump, K.L., Duarte, P., Lean, D.R.S., Trudeau, V.L., 2007. Hormone cross-regulation in the tadpole brain: developmental expression profiles and effect of T3 exposure on thyroid hormone- and estrogen-responsive genes in Rana pipiens. Gen. Comp. Endocrinol. 154 (1-3), 5-15.

Hoopfer, E.D., Huang, L.Y., Denver, R.J., 2002. Basic transcription element binding protein is a thyroid hormone-regulated transcription factor expressed during metamorphosis in Xenopus laevis. Develop. Growth Differ. 44 (5), 365-381.

Hu, X.X., Shi, W., Zhang, F.X., Cao, F., Hu, G.J., Hao, Y.Q., et al., 2013. In vitro assessment of thyroid hormone disrupting activities in drinking water sources along the Yangtze River. Environ. Pollut. 173, 210-215.

Huang, M.-Y., Duan, R.-Y., Ji, X., 2014. Chronic effects of environmentally-relevant concentrations of lead in Pelophylax nigromaculata tadpoles: threshold dose and adverse effects. Ecotoxicol. Environ. Saf. 104, 310-316.

Ishihara, A., Makita, Y., Yamauchi, K., 2011. Gene expression profiling to examine the thyroid hormone-disrupting activity of hydroxylated polychlorinated biphenyls in metamorphosing amphibian tadpole. J. Biochem. Mol. Toxicol. 25 (5), 303-311.

Jagnytsch, O., Opitz, R., Lutz, I., Kloas, W., 2006. Effects of tetrabromobisphenol A on larval development and thyroid hormone-regulated biomarkers of the amphibian Xenopus laevis. Environ. Res. 101 (3), 340-348.

Jia, X.Y., Cai, C.C., Wang, J., Gao, N.N., Zhang, H.J., 2014. Endocrine-disrupting effects and reproductive toxicity of low dose MCLR on male frogs (Rana nigromaculata) in vivo. Aquat. Toxicol. 155, 24-31.

Jugan, M.L., Lévy-Bimbot, M., Pomérance, M., Tamisier-Karolak, S., Blondeau, J.P., Lévi, Y., 2007. A new bioluminescent cellular assay to measure the transcriptional effects of chemicals that modulate the alpha-1 thyroid hormone receptor. Toxicol. in Vitro 21 (6), 1197-1205.

Kitamura, S., Kato, T., Iida, M., Jinno, N., Suzuki, T., Ohta, S., et al., 2005. Anti-thyroid hormonal activity of tetrabromobisphenol A, a flame retardant, and related compounds: affinity to the mammalian thyroid hormone receptor, and effect on tadpole metamorphosis. Life Sci. 76 (14), 1589-1601.

Kudo, Y., Yamauchi, K., Fukazawa, H., Terao, Y., 2006. In vitro and in vivo analysis of the thyroid system-disrupting activities of brominated phenolic and phenol compounds in Xenopus laevis. Toxicol. Sci. 92 (1), 87-95.

Labadie, P., Tlili, K., Alliot, F., Bourges, C., Desportes, A., Chevreuil, M., 2010. Development of analytical procedures for trace-level determination of polybrominated diphenyl ethers and tetrabromobisphenol A in river water and sediment. Anal. Bioanal. Chem. 396 (2), 865-875.

Laudet, V., 2011. The origins and evolution of vertebrate metamorphosis. Curr. Biol. 21 (18), R726-R737.

Li, J., Ma, M., Wang, Z.J., 2008. A two-hybrid yeast assay to quantify the effects of xenobiotics on thyroid hormone-mediated gene expression. Environ. Toxicol. Chem. 27 (1), 159-167.

Li, J., Ren, S.J., Han, S.L., Li, N., 2014. A yeast bioassay for direct measurement of thyroid hormone disrupting effects in water 
without sample extraction, concentration, or sterilization. Chemosphere 100, 139-145.

Livak, K.J., Schmittgen, T.D., 2001. Analysis of relative gene expression data using real-time quantitative PCR and the 2(-Delta Delta C (T)). Method. 25 (4), 402-408.

Lou, Q.Q., Zhang, Y.F., Ren, D.K., Xu, H.M., Zhao, Y.X., Qin, Z.F., et al., 2014a. Molecular characterization and developmental expression patterns of thyroid hormone receptors (TRs) and their responsiveness to TR agonist and antagonist in Rana nigromaculata. J. Environ. Sci. 26 (10), 2084-2094.

Lou, Q.Q., Cao, S., Xu, W., Zhang, Y.F., Qin, Z.F., Wei, W.J., $2014 b$. Molecular characterization and mRNA expression of ribosomal protein L8 in Rana nigromaculata during development and under exposure to hormones. J. Environ. Sci. 26 (11), 2331-2339.

Matsubara, K., Sanoh, S., Ohta, S., Kitamura, S., Sugihara, K., Fujimoto, N., 2012. An improved thyroid hormone reporter assay to determine the thyroid hormone-like activity of amiodarone, bithionol, closantel and rafoxanide. Toxicol. Lett. 208 (1), 30-35.

Mullur, R., Liu, Y.-Y., Brent, G.A., 2014. Thyroid hormone regulation of metabolism. Physiol. Rev. 94 (2), 355-382.

Nakajima, K., Fujimoto, K., Yaoita, Y., 2012. Regulation of thyroid hormone sensitivity by differential expression of the thyroid hormone receptor during Xenopus metamorphosis. Genes Cells 17 (8), 645-659.

Oka, T., Mitsui-Watanabe, N., Tatarazako, N., Onishi, Y., Katsu, Y., Miyagawa, S., et al., 2012. Establishment of transactivation assay systems using fish, amphibian, reptilian and human thyroid hormone receptors. J. Appl. Toxicol. 33 (9), 991-1000.

Opitz, R., Braunbeck, T., Bogi, C., Pickford, D.B., Nentwig, G., Oehlmann, J., et al., 2005. Description and initial evaluation of a Xenopus metamorphosis assay for detection of thyroid system-disrupting activities of environmental compounds. Environ. Toxicol. Chem. 24 (3), 653-664.

Remaud, S., Gothié, J.-D., Morvan-Dubois, G., Demeneix, B.A., 2014. Thyroid hormone signaling and adult neurogenesis in mammals. Front. Endocrinol.(Lausanne) 5, 62. http://dx.doi. org/10.3389/fendo.2014.00062.

Ren, X.M., Guo, L.H., Gao, Y., Zhang, B.T., Wan, B., 2013. Hydroxylated polybrominated diphenyl ethers exhibit different activities on thyroid hormone receptors depending on their degree of bromination. Toxicol. Appl. Pharmacol. 268 (3), 256-263.

Ren, X.M., Zhang, Y.F., Guo, L.H., Qin, Z.F., Lü, Q.Y., Zhang, L.Y., 2015. Structure-activity relations in binding of perfluoroalkyl compounds to human thyroid hormone T3 receptor. Arch. Toxicol. 89 (2), 233-242. http://dx.doi.org/10.1007/ s00204-014-1258-y.

Searcy, B.T., Beckstrom-Sternberg, S.M., Beckstrom-Sternberg, J.S., Stafford, P., Schwendiman, A.L., Soto-Pena, J., et al., 2012. Thyroid hormone-dependent development in Xenopus laevis: a sensitive screen of thyroid hormone signaling disruption by municipal wastewater treatment plant effluent. Gen. Comp. Endocrinol. 176 (3), 481-492.

Shi, Y.B., 2009. Dual functions of thyroid hormone receptors in vertebrate development: the roles of histone-modifying cofactor complexes. Thyroid 19 (9), 987-999.

Shiizaki, K., Asai, S., Ebata, S., Kawanishi, M., Yagi, T., 2010. Establishment of yeast reporter assay systems to detect ligands of thyroid hormone receptors $\alpha$ and $\beta$. Toxicol. in Vitro 24 (2), 638-644.

State Science and Technology Commission in China, 1988. Regulation for the Administration of Affairs Concerning Experimental Animals. The Ministry of Science and Technology of the People's Republic of China, Beijing.
Stolow, M.A., Shi, Y.B., 1995. Xenopus sonic hedgehog as a potential morphogen during embryogenesis and thyroid hormone-dependent metamorphosis. Nucleic Acids Res. 23 (13), 2555-2562.

Sun, H., Shen, O.X., Wang, X.R., Zhou, L., Zhen, S.Q., Chen, X.D., 2009. Anti-thyroid hormone activity of bisphenol A, tetrabromobisphenol A and tetrachlorobisphenol A in an improved reporter gene assay. Toxicol. in Vitro 23 (5), 950-954.

Tata, J.R., 1993. Gene expression during metamorphosis: an ideal model for post-embryonic development. BioEssays 15 (4), 239-248.

Terasaki, M., Kosaka, K., Kunikane, S., Makino, M., Shiraishi, F., 2011. Assessment of thyroid hormone activity of halogenated bisphenol A using a yeast two-hybrid assay. Chemosphere 84 (10), 1527-1530.

The IUCN Red List of Threatened Species, 2014. Pelophylax nigromaculatus (Black-spotted Pond Frog, Dark-spotted Frog). International Union for Conservation of Nature (Available at: http://www.iucnredlist.org/details/58679/0)).

Turque, N., Palmier, K., Le Mével, S., Alliot, C., Demeneix, B.A., 2005. A rapid, physiologic protocol for testing transcriptional effects of thyroid-disrupting agents in premetamorphic Xenopus tadpoles. Environ. Health Perspect. 113 (11), 1588-1593.

Vandenberg, L.N., 2014. Non-monotonic dose responses in studies of endocrine disrupting chemicals: bisphenol A as a case study. Dose-Response 12 (2), 259-276.

Veldhoen, N., Boggs, A., Walzak, K., Helbing, C.C., 2006. Exposure to tetrabromobisphenol-A alters $\mathrm{TH}$-associated gene expression and tadpole metamorphosis in the Pacific tree frog Pseudacris regilla. Aquat. Toxicol. 78 (3), 292-302.

Veldhoen, N., Propper, C.R., Helbing, C.C., 2014a. Enabling comparative gene expression studies of thyroid hormone action through the development of a flexible real-time quantitative PCR assay for use across multiple anuran indicator and sentinel species. Aquat. Toxicol. 148, 162-173.

Veldhoen, N., Skirrow, R.C., Brown, L.L., van Aggelen, G., Helbing, C.C., 2014b. Effects of acute exposure to the non-steroidal anti-inflammatory drug ibuprofen on the developing North American bullfrog (Rana catesbeiana) tadpole. Environ. Sci. Technol. 48 (17), 10439-10447.

Wang, X.D., Matsuda, H., Shi, Y.B., 2008. Developmental regulation and function of thyroid hormone receptors and 9-cis retinoic acid receptors during Xenopus tropicalis metamorphosis. Endocrinology 149 (11), 5610-5618.

Yang, S.W., Wang, S.R., Liu, H.L., Yan, Z.G., 2012. Tetrabromobisphenol A: tissue distribution in fish, and seasonal variation in water and sediment of Lake Chaohu, China. Environ. Sci. Pollut. Res. 19 (9), 4090-4096.

Yen, P.M., 2001. Physiological and molecular basis of thyroid hormone action. Physiol. Rev. 81 (3), 1097-1142.

Zhang, J., Lazar, M.A., 2000. The mechanism of action of thyroid hormones. Annu. Rev. Physiol. 62 (1), 439-466.

Zhang, Y.F., Xu, W., Lou, Q.Q., Li, Y.Y., Zhao, Y.X., Wei, W.J., et al., 2014. Tetrabromobisphenol A disrupts vertebrate development via thyroid hormone signaling pathway in a developmental stage-dependent manner. Environ. Sci. Technol. 48 (14), 8227-8234.

Zoeller, R.T., Tyl, R.W., Tan, S.W., 2007. Current and potential rodent screens and tests for thyroid toxicants. Crit. Rev. Toxicol. 37 (1-2), 55-95. 